\title{
1. INTRODUCTION: OBJECTIVES, STRATEGY, OPERATIONS, SHIPBOARD ANALYTICAL PROCEDURES, AND EXPLANATORY NOTES OF DEEP SEA DRILLING PROJECT LEG 54
}

\author{
Bruce R. Rosendahl, ${ }^{1}$ Roger Hekinian, ${ }^{2}$ James H. Natland, ${ }^{3}$ Nick Warren, ${ }^{4}$ \\ Nikolai Petersen, ${ }^{5}$ William Roggenthen, ${ }^{6}$ and Louis Briqueu ${ }^{2}$
}

\section{BACKGROUND, OBJECTIVES, AND STRATEGY}

The Pacific phase of IPOD ocean crust drilling was initiated with Leg 54, the region targeted for study by the Ocean Crust Panel being survey area PT-4 (Figure 1) (and Plate 1 [in back pocket]) north of the Siqueiros fracture zone on the western flank of the East Pacific Rise (EPR). The original purpose of this leg was to establish a type section for fast-spreading, nonrifted crust by direct sampling with stratigraphic control. We anticipated that this section would serve, in part, as a standard of comparison for other type sections, such as the Mid-Atlantic Ridge (MAR).

To achieve the stated objective, we devised an elaborate strategy for the selection and chronologic sequencing of holes and an array of tests to choose the location of the multiple re-entry type area site (Figure 2). An important part of this strategy was to locate a spot where a deep re-entry hole could be drilled several hundred meters into normal, fast-spreading oceanic crust. However, by the time we had terminated drilling at only a few holes, the vagaries of nature had made it abundantly clear that the strategy for Leg 54 , indeed its original purpose, was as yet technologically unrealistic. The main difficulty was the intensely fractured state of the basaltic crust, effectively limiting penetration to a depth at which frictional binding of the drill stem became so great that continued drilling became impossible, and/or resulted in obliteration of the core bit. Even the fact that 30 -meter holes into basement were obtained is a tribute to the dedication, expertise, and persistence of the drillers, not a lessening of nature's contrariness. Similar difficulties had been experienced on Leg 34 on the Nazca plate, but we had hoped that successful deep crustal drillings in the Atlantic on Legs 37

\footnotetext{
${ }^{1}$ Department of Geology, Duke University, Durham, North Carolina.

${ }^{2}$ Centre Océanologique de Bretagne, Brest, France.

${ }^{3}$ Deep Sea Drilling Project, Scripps Institution of Oceanography, La Jolla, California.

${ }^{4}$ Department of Geology, University of California, Los Angeles, California.

5 Institut für Allgemeine und Angewandte Geophysik, LudwigMaximilians-Universität, Munich, Federal Republic of Germany.

${ }^{6}$ Department of Geological and Geophysical Sciences, Princeton University, Princeton, New Jersey (now at: South Dakota School of Mines and Technology, Department of Geology, Rapid City, South Dakota).
}

and 45 had "taught" us how to drill oceanic crust. Experience, however, proved woefully inadequate to deal with the difficulties encountered on Leg 54 . These difficulties necessitated an on-the-spot re-evaluation of the goals of Leg 54 and the development of an appropriate strategy, both of which were based upon what could be learned from low-penetration, single-bit holes. Also, an unscheduled drilling program on the flanks of the Galapagos spreading center (GSC), supplemental to that in survey area PT-4, was set up.

As perceived by the scientific party, it was no longer possible to establish a type section for fast-spreading crust, but we could drill a transect of relatively shallow, single-bit holes that would span the same geological period as covered by one successful deep hole. By doing so, we would still be able to answer important questions regarding (1) temporal variations and timing of eruptive events at the EPR and their relationship to postulated axial magma reservoirs; (2) the cause of the apparently greater extent of basalt fractionation observed in EPR dredged rocks than in MAR basalts; (3) magnetization polarities of drilled rocks and their comparison to results in the Atlantic; and (4) the relation of physical properties to the degree of alteration, weathering, crystallinity, and fracturing. Moreover, by allowing the transect to cross an off-ridge volcanic lineament, we hoped to learn something about the chemical, magnetic, and physical nature of the transition from EPR fabric to transverse volcanic and structural features. The above strategy and objectives formed the framework for the drilling program in survey area PT-4.

The Galapagos program originated as a DSDP directive while en route to our sixth site in area PT-4. The object of the directive was to conduct "drilling trials along the Galapagos Spreading Center" for the sake of the "overall [Deep Sea Drilling] Project and IPODJOIDES plans," and to this end we were given specific targets in the Galapagos area. The main purpose of this program was to determine whether a proposed two-leg drilling program in the Galapagos area was feasible, in light of the difficulties encountered in area PT-4, and, if so, what modifications should be made to that program. The directive required the location and drilling of supposed geothermal area south of the Galapagos spreading axis. This area contained several groups of small sedimentary mounds and cones no larger than the Glomar Challenger herself, which we thought had been formed by localized hydrothermal activity, perhaps 


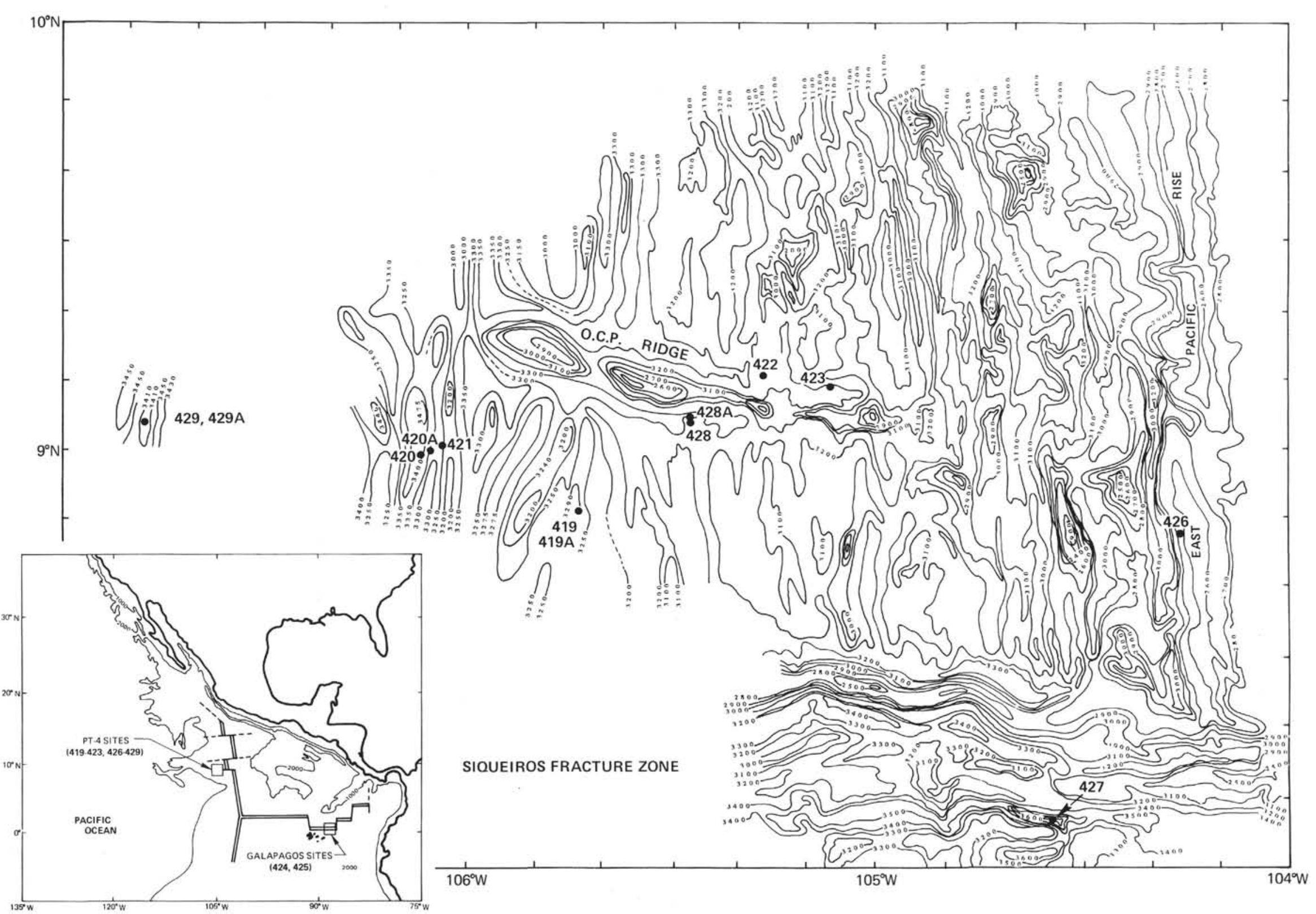

Figure 1. Leg 54 drill sites on the western flank of the East Pacific Rise. Inset: Location of Leg 54 principal target areas in the eastern Pacific. 


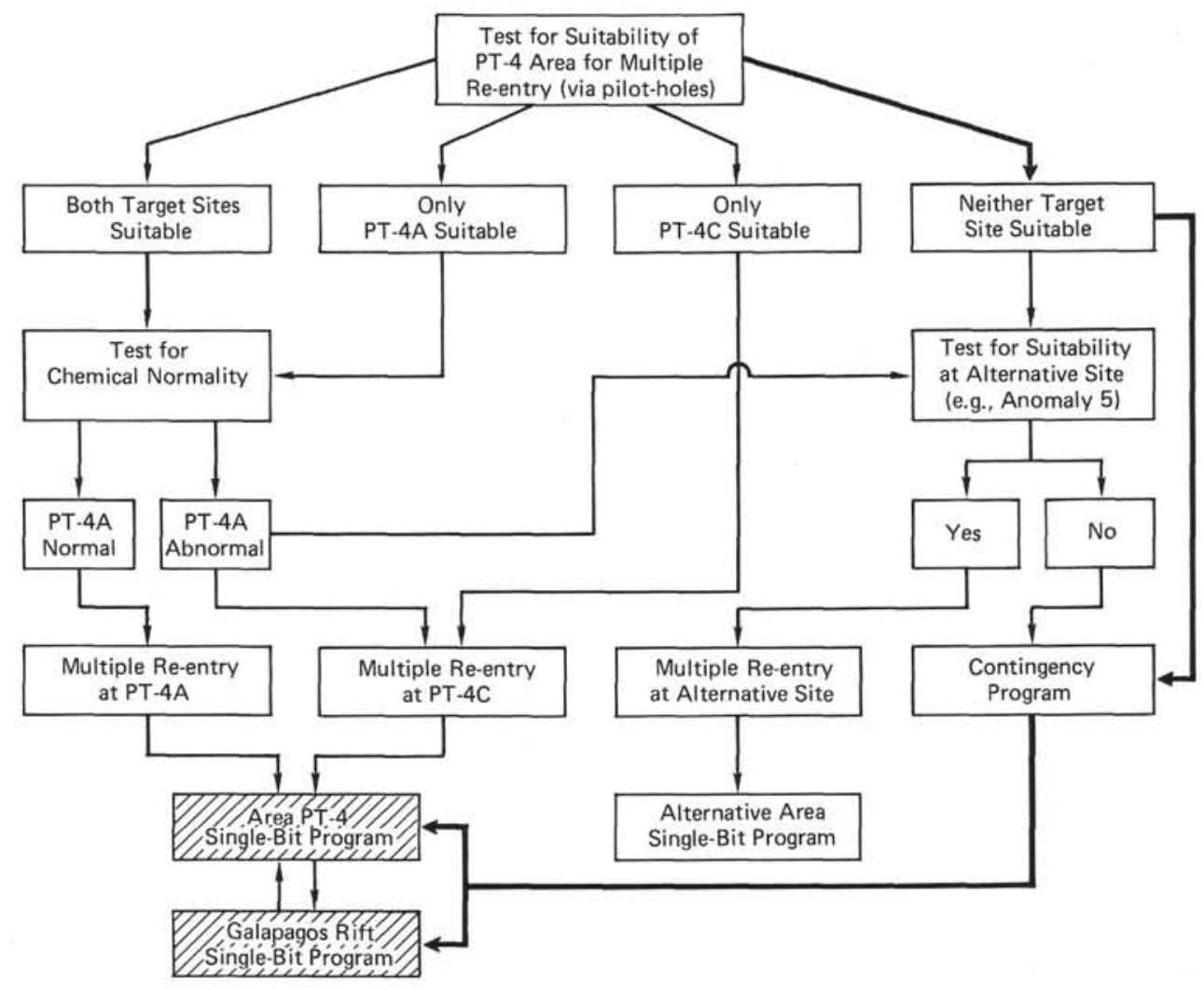

Figure 2. Flow diagram of the original recommended drilling strategy for Leg 54 . The stippled boxes indicate the program we eventually carried out, but by the pathway shown by heavy arrows.

along basement faults and fissures. Other targets on older crust were given, which were to be drilled as time allowed.

Although most members of our scientific party were unfamiliar with the mounds area, and we had virtually no survey data to find them, we accepted the Galapagos challenge and devised a set of scientific objectives and strategies compatible with both the purpose of the Galapagos diversion and the goals of ocean crust drilling. The objectives pertained to: (1) the origin of the Galapagos mounds and their relationship to hydrothermal circulation patterns in young crust, (2) the internal stratigraphy and constitution of the mounds and the physicochemical nature of basement beneath and between the mounds, and (3) Galapagos equivalents of the EPR objectives listed above. The strategy entailed locating the mounds' field with a high-frequency, fastsweep profiling system and deploying a beacon as close to an individual mound as possible. The Edo re-entry sonar scanning tool would then be used to position the ship for spud-in accurately over a mound. Once a mound had been drilled, we would move north-south from the beacon and establish a minitransect of holes across one or more mound chains. A site would also be placed on a known heat-flow maximum far removed from the transect area to provide additional insight into the nature and diversity of sea-floor hydrothermal activity.

The inadequacy of onboard Galapagos survey data deserves special mention, because it played a critical role in the drilling program we devised. There had not been a site survey in the Galapagos area (as there had been at the EPR area), and it was by pure accident that we had any relevant literature aboard at all. This literature consisted of a paper by Sclater and Klitgord (1973) containing a small $(4 \times 5$ in.) general bathymetric map of the area and a few reflection profiles, and a first-draft preprint of a paper later published by Lonsdale (1977) dealing with deep-tow observations in the mounds locality. This latter manuscript, along with its figures, constituted the sum total of information we possessed on the supposed geothermal area prior to drilling. We used this information to find the mounds and to identify the specific parts of the mounds' field drilled. One other critical factor was the severe time restriction imposed by having to include a 13-day round trip between the Siqueiros and Galapagos areas within a cruise already considerably shortened by termination at Long Beach, rather than Mexico, for necessary dry-docking. In all, Leg 54 had 19 days of operations (drilling and steaming) in its target areas, out of a 50-day cruise. At the end of our Galapagos drilling a cruise extension of five days 
for additional operations was granted at the urgent appeal of the Leg 54 shipboard party. We used this extension to return to the Siqueiros area and continue our program there. In our 19 days of operations we drilled 18 holes at 11 sites.

Even though the EPR and GSC drilling programs shared many of the same hard-rock objectives, each program stands alone with respect to its achievements and scientific appeal. In a very real and practical sense the programs are as different from each other as any two crustal drilling legs, and for this reason we treat each as a separate entity within this volume. Moreover, since each program consists mainly of transects of holes closely related in terms of purpose, operations, and results, we have elected not to assign chapters to individual sites. Instead, the Site Reports are grouped into two chapters under EPR and Galapagos headings. We think the above conventions will result in a more readable and concise volume.

\section{OPERATIONS}

The Glomar Challenger left Cristobal, Panama, on the morning of 30 April 1977, to begin transit through the Panama Canal. Because of a malfunction first in the No. 4 generator, and then the electrical circuitry for the stern thrusters, our departure from Panamanian waters was delayed until 2030 hours, 1 May. We arrived in San Pedro, California, on the morning of 18 June 1977.

During Leg 54, the ship traveled 6333 nautical miles, occupied 11 sites, attempted to drill 18 holes, and successfully penetrated basement at 13 localities. Water depths ranged from 2617 to 3834 meters. Total penetration was 1282 meters, of which 847 meters of material was cored and 461 meters recovered. Basement penetration totaled 324.5 meters, but only 66 meters of basalt was recovered. Coring data for Leg 54 are given in Table 1 . Sites 419 through 423 and 426 through 429 were drilled in the Siqueiros area (within survey area PT-4) and Sites 424 and 425 on the flanks of the Galapagos rift (Figure 1).
By using the official starting date of 25 April 1977 for Leg 54, the time distribution was as follows: 4.6 days in port including 0.7 day of downtime, 32.6 days in transit, and 17.8 days on site (Figure 3 ). The on-site time breakdown was 8.6 days for coring, 6.1 days for pulling pipe, 1.5 days for ship positioning, 0.4 day of mechanical downtime, 0.2 day of drilling, 0.1 day for a stuck drill pipe, and 0.9 day of miscellaneous time (Figure 4).

We had our share of "ups and downs," successes and failures, agreements and disagreements. On the positive side, Leg 54 occupied more sites and drilled more basement holes than any previous IPOD leg. We drilled the youngest basement of any DSDP leg and proved that successful spud-in was possible where sediment cover was as thin as 29 meters. In addition, Leg 54 established the practicality of locating and drilling Challenger-sized structures on the sea floor. In the success column, we also list the attitude, understanding, and diligence of the Leg 54 drilling crew, to whom this volume is informally dedicated. On the negative side, our deepest penetration into basement and average bit life were less than those achieved on any previous crustal drilling leg, and average hole conditions were the worst ever encountered. Moreover, the percentage of on-site time devoted to actual drilling was a meager 1.1 per cent and our ratio of in-transit time to days on station was almost 2:1.

In view of the large number of holes, the extremely unfavorable conditions at the holes, and inherent dangers of spudding into basement with minimal sediment cover, Leg 54 was remarkably free of mechanical breakdowns. The most serious operational failure occurred prior to any drilling and involved the inoperative state of the blower shaft on the gel pump. The gel had been expected to improve hole conditions significantly by aiding in the removal of drilling chips; consequently, there was some consternation when this ability appeared lost for the remainder of the leg. However, toward the end of the cruise an alternative pumping system was jury-rigged and gel was used on Site 428 . There was no noticeable improvement in drilling conditions. The only

TABLE 1

Coring Summary, Leg 54

\begin{tabular}{|c|c|c|c|c|c|c|c|c|c|c|c|}
\hline Hole & Date (1977) & Latitude & Longitude & $\begin{array}{l}\text { Water } \\
\text { Depth } \\
\text { (m) }\end{array}$ & $\begin{array}{l}\text { Penetration } \\
\text { (m) }\end{array}$ & $\begin{array}{c}\text { Number } \\
\text { of } \\
\text { Cores }\end{array}$ & $\begin{array}{l}\text { Cored } \\
(\mathrm{m})\end{array}$ & $\begin{array}{l}\text { Recovered } \\
\text { (m) }\end{array}$ & $\begin{array}{l}\text { Recovery } \\
(\%)\end{array}$ & $\begin{array}{c}\text { Basement } \\
\text { Penetration }(\mathrm{m})\end{array}$ & $\begin{array}{c}\text { Basement } \\
\text { Recovery (m) }\end{array}$ \\
\hline 419 & 8-9 Мау & $08^{\circ} 55.96^{\prime} \mathrm{N}$ & $105^{\circ} 41.17^{\prime} \mathrm{W}$ & 3274 & 35.0 & 5 & 35.0 & 21.64 & 62 & 0 & 0 \\
\hline $419 A$ & 9 May & $08^{\circ} 55.47^{\prime} \mathrm{N}$ & $105^{\circ} 41.22^{\prime} \mathrm{W}$ & 3274 & 46.0 & 1 & 8.0 & 4.74 & 59 & 0 & 0 \\
\hline 420 & 10-11 May & $09^{\circ} 00.10^{\prime} \mathrm{N}$ & $106^{\circ} 06.77^{\prime} \mathrm{W}$ & 3381 & 147.0 & 17 & 147.0 & 95.07 & 65 & 28.7 & 1.22 \\
\hline $420 \mathrm{~A}$ & $11-12 \mathrm{May}$ & $09^{\circ} 00.50^{\prime} \mathrm{N}$ & $106^{\circ} 06.32^{\prime} \mathrm{W}$ & 3382 & 63.0 & 1 & 6.0 & 6.05 & 100 & 0 & 0 \\
\hline 421 & 12-13 May & $09^{\circ} 01.41^{\prime} \mathrm{N}$ & $106^{\circ} 03.68^{\prime} \mathrm{W}$ & 3339 & 114.0 & 4 & 38.0 & 11.22 & 30 & 19.18 & 1.63 \\
\hline 422 & 14-15 May & $09^{\circ} 10.59^{\prime} \mathrm{N}$ & $105^{\circ} 16.27^{\prime} \mathrm{W}$ & 3247 & 73.0 & 10 & 73.0 & 46.97 & 64 & 23.5 & 9.56 \\
\hline 423 & 15-16 May & $09^{\circ} 08.81^{\prime} \mathrm{N}$ & $105^{\circ} 06.57^{\prime} W$ & 3161 & 53.5 & 8 & 53.5 & 27.98 & 52 & 15.5 & 0.87 \\
\hline 424 & 23-24 May & $00^{\circ} 35.63^{\prime} \mathrm{N}$ & $86^{\circ} 07.82^{\prime} \mathrm{W}$ & 2685 & 76.0 & 8 & 76.0 & 36.45 & 48 & 38.5 & 8.45 \\
\hline $424 \mathrm{~A}$ & 24 May & $00^{\circ} 35.33^{\prime} \mathrm{N}$ & $86^{\circ} 07.81^{\prime} W$ & 2708 & 34.0 & 3 & 34.0 & 13.13 & 39 & 45.01 & 8.45 \\
\hline $424 B$ & $25 \mathrm{May}$ & $00^{\circ} 35.82^{\prime} \mathrm{N}$ & $86^{\circ} 07.82^{\prime} W$ & 2705 & 46.5 & 6 & 46.5 & 29.30 & 63 & 14.5 & 2.35 \\
\hline $424 \mathrm{C}$ & 25 May & $00^{\circ} 35.93^{\prime} \mathrm{N}$ & $86^{\circ} 07.82^{\prime} \mathrm{W}$ & 2699 & 34.5 & 3 & 16.5 & 7.81 & 47 & 3.0 & 0.48 \\
\hline 425 & 26-27 May & $01^{\circ} 23.68^{\prime} \mathrm{N}$ & $86^{\circ} 04.22^{\prime} \mathrm{W}$ & 2850 & 110.0 & 9 & 81.5 & 43.42 & 53 & 28.5 & 5.60 \\
\hline 426 & 3 June & $08^{\circ} 47.28^{\prime} \mathrm{N}$ & $104^{\circ} 15.27^{\prime} \mathrm{W}$ & - & 0.0 & 0 & 0.0 & 0.00 & 0 & 0 & 0 \\
\hline 427 & 4-5 June & $08^{\circ} 06.79^{\prime} \mathrm{N}$ & $104^{\circ} 36.35^{\prime} \mathrm{W}$ & 3834 & 174.5 & 11 & 98.5 & 57.26 & 58 & 28.5 & 12.51 \\
\hline 428 & 6-7 June & $09^{\circ} 02.77^{\prime} \mathrm{N}$ & $105^{\circ} 26.14^{\prime} \mathrm{W}$ & 3295 & 76.5 & 6 & 54.5 & 36.34 & 67 & 15.5 & 2.14 \\
\hline $428 \mathrm{~A}$ & $7-8$ June & $09^{\circ} 02.77^{\prime} \mathrm{N}$ & $105^{\circ} 26.14^{\prime} \mathrm{W}$ & 3286 & 115.0 & 7 & 52.5 & 16.37 & 31 & 52.50 & 12.60 \\
\hline 429 & 9 June & $09^{\circ} 02.01^{\prime}$ is & $106^{\circ} 46.35^{\prime} \mathrm{W}$ & 3406 & 31.0 & 1 & 5.0 & 4.67 & 93 & 0 & 0 \\
\hline $429 \mathrm{~A}$ & 9-10 June & $09^{\circ} 02.01^{\prime} \mathrm{N}$ & $106^{\circ} 45.87^{\prime} \mathrm{W}$ & 3426 & 52.5 & 3 & 21.5 & 2.95 & 14 & 21.5 & 2.95 \\
\hline Total & & & & & & 103 & 847.0 & 461.37 & 54 & 334.39 & 68.81 \\
\hline
\end{tabular}



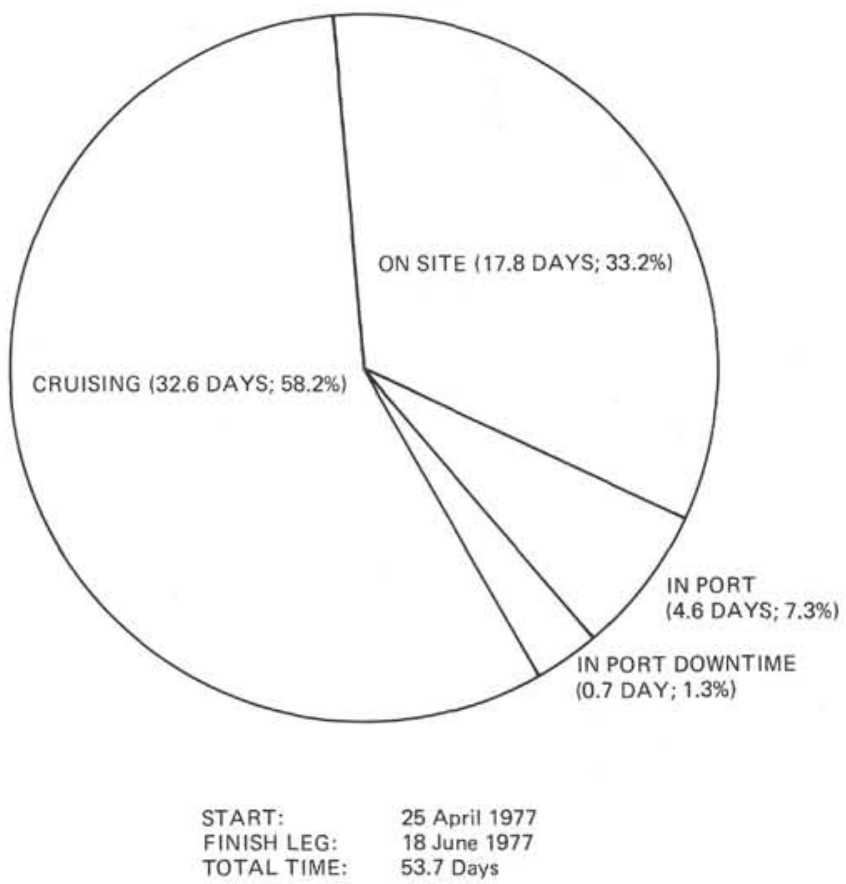

Figure 3. Total time distribution, Leg 54.

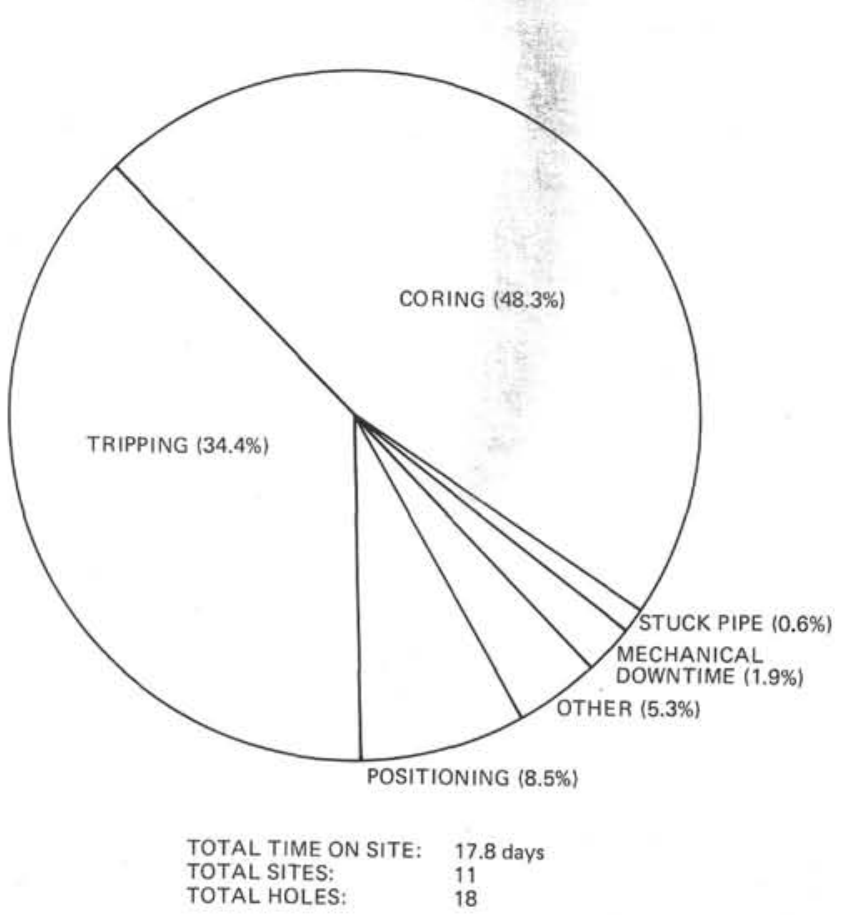

Figure 4. On-site time breakdown, Leg 54.

other serious breakdown involved the diaphragm and clutch lining in the make-up drum for the drawworks requiring 5 hours to repair while on Site 421 .

Ship positioning and weather were generally excellent throughout Leg 54 and probably played an important role in reducing on-site mechanical failures. The shipboard positioning computer was almost trouble-free, although beacon failures occurred at Sites 419 and 426 .

\section{INSTRUMENTATION, EQUIPMENT, AND PROCEDURES}

\section{X-Ray Fluorescence (XRF) Chemical Analyses}

During Leg 54, the equipment and technique used to perform chemical analyses onboard Glomar Challenger were the same as those on previous crustal drilling legs (Legs 37, 45, 46, 47, 51, 52, and 53). The instruments included an XRF unit, a furnace, a motor-driven crusher, a balance, and two cooling systems. The general procedures to perform chemical analyses and description of the equipment are given in Bougault (1977) and Melson, Rabinowitz, et al. (1978). The routine analytical work consisted of making glass disks for major elements and powdered disks pressed with wax for trace elements. The matrix effect in the glass pellets is eliminated by using a mixture of $\mathrm{Li}_{2} \mathrm{~B}_{4} \mathrm{O}_{7}(3.5 \mathrm{~g})$ and $\mathrm{La}_{2} \mathrm{O}_{3}(0.5 \mathrm{~g})$. The elements (as oxides) analyzed during Leg 54 were: $\mathrm{SiO}_{2}, \mathrm{Al}_{2} \mathrm{O}_{3}, \mathrm{Fe}_{2} \mathrm{O}_{3}$ (total $\mathrm{Fe}$ as $\mathrm{Fe}_{2} \mathrm{O}_{3}$ ), $\mathrm{MgO}, \mathrm{CaO}$, $\mathrm{K}_{2} \mathrm{O}$, and $\mathrm{TiO}_{2}$. The standards used during this leg were the following: W-1, BCR1, PCC1, DTS1, G2, GST1, GH (Nancy), and VBR (Nancy).

\section{Equipment and Technical Problems}

During Leg 51, the restricted sample holder was changed to one with a six-position compartment device. Toward the end of Leg 53 a complementary safety device (conceived by the marine technician group) was added on the sample chamber of the XRF unit. The device prevents the operator, who previously had not turned off the high-voltage knob, from being exposed to $\mathrm{X}$-ray irradiation. The unit consists of a solenoid activated by a lever, which mechanically locks the sample chamber door whenever the high-voltage switch is on. A compression spring in the solenoid retracts the locking arm only if the generator is off or in standby position. (Details of the system are described in the Laboratory Officer notebook of Leg 53.) Direct access to the X-ray tube is prevented should it be necessary to replace the $\mathrm{X}$-ray tube, and the mechanical lock mounted on the side of the sample holder has first to be removed.

\section{Limitations of Leg 54 Shipboard XRF Analyses}

The shipboard XRF instrument was not fully operational during the early part of Leg 54 and ceased operating altogether after drilling Hole 424. Difficulties were encountered with both the auxiliary (Newman) cooling system unit and the X-ray spectral lines discriminator. The cooling unit eventually was made to function, despite its high-temperature environment (sea-water temperature was high). The role of the sinusoidal amplifier of the XRF equipment is to regulate and modify the impulse received when the crystal is positioned at the correct angle of diffraction for a specific energy level, as well as to regulate the discriminative channels and the high voltage readout. Even during the first part of the cruise, the sinusoidal amplifier did not furnish the proper signal impulses to the discriminator. Hence, the various energy levels characterizing each analyzed element had to be changed accordingly. This made the 
chemical analyses obtained under such conditions both difficult to acquire and unreliable. To minimize the limits of uncertainty, it was necessary to change the discriminator settings and increase the voltage of the gaseous flux above the maximum voltage recommended by the manufacturers. By changing the discriminator settings, interference was increased between the analyzed energy level of the spectrum and that of the higher order level. For example, to obtain the intensity $\mathrm{K} \alpha$ of $\mathrm{Fe}$, we had to increase the voltage to 2200 volts, thereby generating noticeable instability for this element.

Nonetheless, we were able to measure some of the major oxides with adequate precision, particularly $\mathrm{CaO}$, $\mathrm{K}_{2} \mathrm{O}$, and $\mathrm{TiO}_{2}$. Total $\mathrm{Fe}$, calculated as $\mathrm{Fe}_{2} \mathrm{O}_{3}$, also could be obtained, but with less precision. The analytical results for the other major oxides, such as $\mathrm{SiO}_{2}$, $\mathrm{Al}_{2} \mathrm{O}_{3}$, and $\mathrm{MgO}$, were even less satisfactory, and trace elements were impossible to determine. After completion of the cruise, the rocks recovered on Leg 54 were reanalyzed on the beach by L. Briquieu. These revised analyses form the basis for discussions in the Site Reports and are those listed on the Site Report basalt description forms.

\section{Paleomagnetics}

Equipment on board ship used in the paleomagnetic study of recovered material includes a Digico spinner magnetometer with its associated Digico M16V computer and a Schonstedt geophysical specimen demagnetizer (Model GSD-1). A portable magnetic susceptibility bridge (Geophysics Specialty Co., Model MS-3) was also used.

The primary goal of the paleomagnetic investigations was to determine the original magnetic remanence direction acquired by the igneous material upon cooling. This type of remanence is a thermal remanent magnetization, but it is often not the only kind of remanence which may be present in the rock. During the interval between cooling and measurement in the laboratory, the rock may acquire secondary remanences such as chemical and viscous magnetizations. To eliminate these secondary directions and to establish the "stable direction," a program of stepwise AF demagnetization was employed. Because the AF demagnetizer is a uniaxial model, each specimen was successively demagnetized along the three principal axes of the specimens at each demagnetization step. Peak AF fields as high as $1000 \mathrm{Oe}$ were employed, although fields at which stable directions were reached are commonly much lower. In order to characterize the igneous samples more fully, the susceptibilities were measured and the Königsberger ratio calculated from the relationship:

$$
Q=\frac{J_{N R M}}{\chi \times H}
$$

where $J_{N R M}$ is the volumetric NRM intensity, $\chi$ is the susceptibility, and $H$ is the magnitude of the earth's field at this location $(H=0.36 \mathrm{Oe})$.
We determined a sample's "stable" direction by examining its change in inclination upon progressive demagnetization. If during this process the inclination reached a value that did not change materially for several steps, this was termed the "stable" direction. Change in declination was also considered but was not used as the determining parameter. As a measure of inherent stability, the median demagnetizing field (MDF) was found for each sample. This is the AF field necessary to eliminate half of the original intensity of magnetization (see Figure 5).

Because the rock samples can be oriented solely with respect to the vertical axis, only the inclinations can be determined as absolutes. Declinations are relative values and are referred to the face of the split core.

The low latitudes at which the sites were drilled created some problems in the determination of polarity; inclinations expected at the latitudes of the Siqueiros survey area PT- 4 are only about $18^{\circ}$. Therefore, some

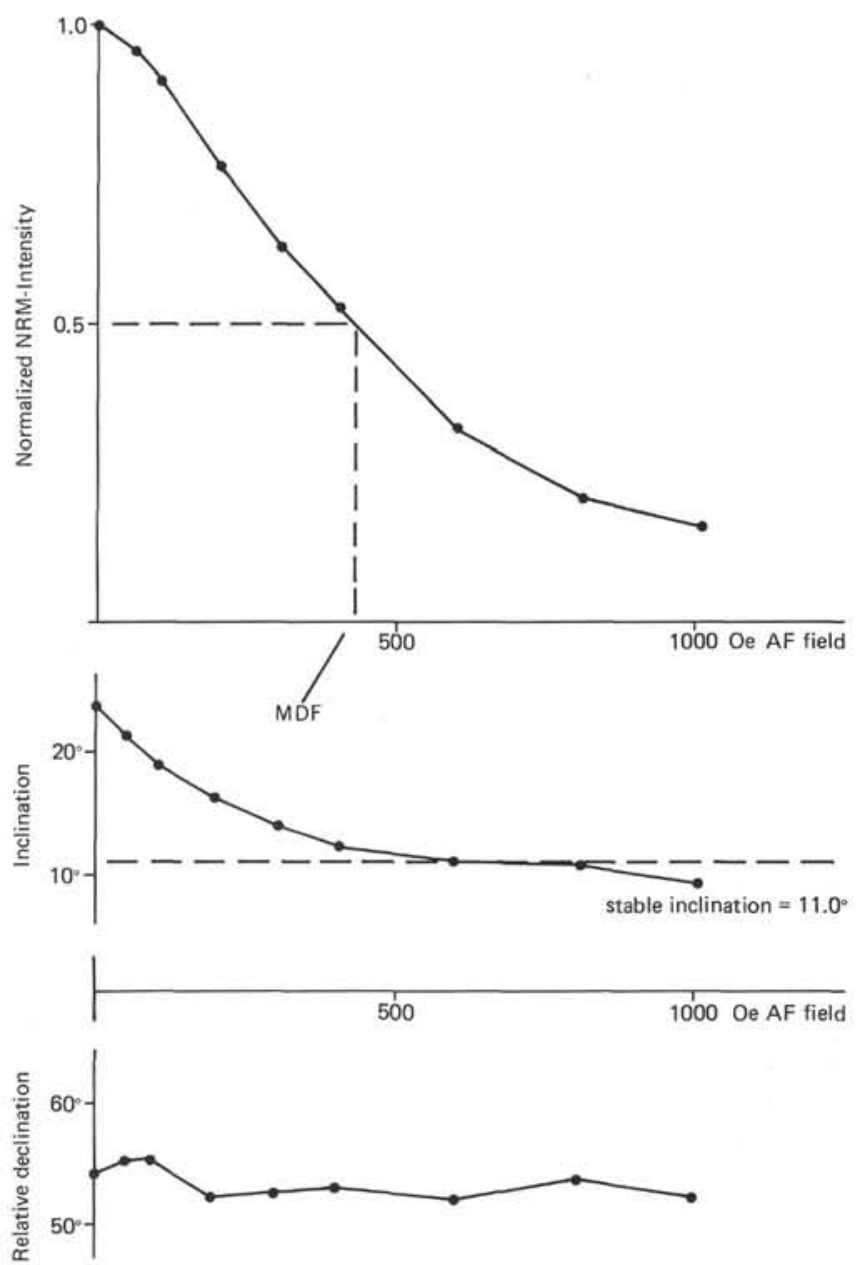

Figure 5. Example of the determination of the median demagnetizing field (MDF) and stable magnetic inclination of the natural remanent magnetization (NRM). The inclination is given in absolulte values, the declination in relative values. 
attempts were made to orient the cores using differences between low-value demagnetization steps to ascertain viscous remanences most likely associated with the present-day field. This procedure also assists in determining the declinations.

In summary, the shipboard measurements included: (1) determination of NRM and subsequent directions after demagnetization to establish the "stable" directions (inclinations) for each sample, (2) determination of intensities before and after demagnetization, and (3) measurement of susceptibilities and calculation of Königsberger $Q$ ratios. These data are given on the basalt description forms in the Site Reports.

\section{Physical Properties: Introduction}

The physical properties of recovered cores provide a base line for interpreting geophysical data obtained from ocean-bottom and shipboard surveys. A chief objective of Leg 54 was to compare core properties and survey properties. The goal of the leg was to characterize the normal fabric of young ocean crust near the EPR Detailed presite surveys had been made and a re-entry hole was planned. As already described, this objective could not be met because of the impossibility of drilling a re-entry hole and even of making any deep single-bit holes.

Although the primary objective was lost, the low recovery still enabled us to make detailed shipboard studies on the recovered samples. Sound velocities, bulk densities, grain densities, water content, porosities, and shear strength were measured in sediments and basalts. Additional velocity, grain, and bulk-density measurements were made post-cruise on a number of samples at UCLA (Warren and Rosendahl, this volume).

These primary data are presented in the Site Reports, this volume. Generally, more accurate data were obtained for the basalt than for the sediments. The rock samples consist chiefly of fragments of very dense, hard basalts. At three sites where sills or thick flows were encountered, drilling was good and fairly continuous sampling was possible.

For the basalts, Birch-law systematics and the effect of average iron content are clearly visible in the shipboard velocity-density data. The data also show velocity, density systematics within basalt units (which in turn may be used to correlate with grain-size), cooling rates, and magnetics.

Sediments were generally soft oozes at all sites, and frequently the cores were moderately to highly disturbed. The physical properties of the sediments were very uniform except at the Galapagos sites. There, the foraminifer and nannofossil oozes were interbedded with iron and magnesium-rich green muds which showed higher densities and velocities than the pelagic sediments in the Siqueiros PT-4 locales.

\section{Techniques}

\section{Density Measurements \\ Gamma-Ray Attenuation Porosity Evaluator (GRAPE)}

Densities and porosities of materials can be determined by measuring their attentuation of a beam of gamma rays. The equipment and technique for doing this by the onboard gamma-ray absorption instrument have been fully described in earlier reports (Boyce, 1976).

On this leg the GRAPE was used conventionally. Continuous logs of the sediment cores were made routinely. Some 2-minute GRAPE counts were made of sediment minicores.

Only one section of basalt was logged continuously. Two difficulties were encountered in trying to log the rock cores. First, the cores were seldom continuous and, typically, consisted of loose fragments of very fresh basalts with very little glass. Therefore, they were not obviously characteristic of an in-situ rock column. Second, we found the cores were iron-rich basalts (up to 15 per cent $\mathrm{Fe}$ as $\mathrm{Fe}_{2} \mathrm{O}_{3}$ ), so that grain densities for many of the samples were over $3.00 \mathrm{~g} / \mathrm{cm}^{3}$.

Because bulk and grain densities were abnormally high, we found that the densities determined by the GRAPE were significantly off from values determined by weight and volume measurements on minicores that were carefully prepared for the velocity measurements. Use of the "standard" grain density values assumed for reducing raw data to density and porosity often gave negative porosities. It was clear that porosities and densities had to be determined more accurately than could be done by using the standard program. GRAPEing whole sections or whole rough rocks yielded neither real information about in situ densities nor accurate data on rock densities themselves. Therefore, wet- and dry-bulk densities were determined using weight and volume measurements on the carefully prepared minicores.

Two-minute GRAPE counts were made on the minicores for later reduction to densities. On some samples, grain density and porosity estimates were made using wet and dry weight data from the same minicore. This could be done with considerable accuracy for cut and lapped minicores which could be weighed both wet and dry; samples from Site 425 were dealt with in this way. Assuming salt corrections, the grain density of the sample could be solved from

$$
\rho_{\mathrm{g}}=1.025 \frac{\phi^{\prime}}{1-\phi^{\prime}}\left(\frac{0.965}{K}-0.035\right)
$$

where $\phi^{\prime}$ is the true porosity and $K$ is defined by

$K=\frac{\text { wet weight }- \text { dry weight }}{\text { dry weight }}$ (no salt corrections). 


\section{Velocity Measurements}

Compressional velocities $\left(V_{p}\right)$ were measured at zero confining pressure on water-saturated samples. A scaling wave technique for measuring velocity, which took advantage of the shipboard Tektronix 485 oscilloscope, was set up. This was both easier and faster than the standard method, as well as being inherently more accurate. Visual detection of the onset of an acoustic signal was facilitated and the uncertainty of measuring its arrival time reduced. The method required the addition of a voltage-controlled frequency and sweep-generator and a frequency counter to the ship's regular velocity measuring system. Both of these additional instruments were available onboard ship.

We shall briefly describe the idea underlying the method. A scaling wave is a gated sinusoidal wave which is visually displayed on the oscilloscope along with the acoustic signal itself. The starting time for the scaling wave $(t=0)$ is set to coincide with the arrival time of an acoustic wave through the Hamilton Frame sample holder, with no sample.

When a sample is placed in the holder, the arrival of the acoustic signal is further delayed from $t=0$ by some interval $t$. By simply adjusting the frequency, the scaling wave can be stretched or compressed exactly like a Gerber scale to divide this delay time $t$ by an integral number of waves. The travel time is then given by

$$
t=N / f
$$

where $N$ is the number of cycles and $f$ is the frequency. The velocity $V$ is then

$$
V=L / t=L \cdot N / f
$$

where $L$ is the sample length. (Operational instructions for using the scaling-wave technique are described in the Appendix.)

In the case of basalts, minicore samples were made for accurate velocity and density measurements. The general procedure involved splitting and taking minicores from rocks directly after they were brought in from the drilling platform. The minicores were then placed in 10 bottles filled with sea water and capped and returned to their location in the section until curatorial work was completed. This kept these samples fully saturated. The rough end of the minicore was later sawed off and used for thin sections. A polishing block was built and used to lap the ends of the minicores to parallel (usually to less than $\pm 0.02 \mathrm{~mm}$ ). Velocities, magnetics, and bulk densities were then determined on the cores.

Because most of the sediments were very soft, their velocities were usually determined on the split cores still in the liners.

The length $L$ of the basalt minicore was measured with a caliper. The lengths of the split sediment cores were measured directly off the micrometer wheel on the Hamilton Frame, and standard core liner corrections of $L$ (liner) $=2.56 \mathrm{~mm}$ and $t$ (liner) $=1.18 \mu \mathrm{s}$ were used in reducing the data.
Using brass, aluminum, and plexiglas standards, the system was checked and calibrated frequently during the leg by one of two methods. Either standards, such as aluminum and lucite, were measured simply as if they were samples, or the system was calibrated to one of the standards and then the other standards were measured. This calibration was done by first placing the standard into the Hamilton Frame. A scaling wave frequency was chosen and the visual start of the scaling wave was then adjusted so that there were exactly $N$ cycles in the scaling wave to the start of the acoustic signal.

Assuming the true velocity of the standard to be correct, the travel time of the acoustic signal through the standard was of course known. This gave "zero" error for the velocity measurement of the chosen standard, and other standards or samples could be measured relative to it.

Table 2 shows some calibration data. The values determined for the velocities seldom varied more than \pm 0.5 per cent from the "true" values.

\section{Other Measurements}

a) Shear strengths:

These were measured using the hand-held Torr-vane gauge.

b) Water content:

Water content, bulk densities, and porosities were determined for the sediments using $3-\mathrm{cm}^{3}$ syringe samples. Procedures were routine, as described by Boyce (1976). These measurements were also used to estimate grain density $\left(\rho_{g}\right)$ for comparison with that assumed $\left(\rho_{g c}\right)$ in the inversion of the GRAPE data $\left(\rho_{g c}=2.7 \mathrm{~g} / \mathrm{cm}^{3}\right)$.

Grain densities can be calculated from the water content $(C)$, and the porosity $(\phi)$ by the equation

$$
\rho_{g}=\left(\frac{1-C}{C}\right) \cdot\left(\frac{\phi}{1-\phi}\right)
$$

where ${ }_{g}$ is the grain density. Equation 1 assumes no salt corrections and a water density of 1.00 . Salt corrections and sea-water density can be included, resulting in equation (6).

$$
\rho_{g}=1.025\left(\frac{\phi}{0.989-\phi}\right) \cdot\left(\frac{0.965-C}{C}\right)
$$

where $C$ and $\phi$ are the directly calculated (non-salt corrected) water content and porosity, respectively.

A computer program was written to calculate grain densities on shipboard using Equation (6). The average value calculated was close to $\rho_{g c}$. This is discussed in the Site Report section on physical properties of sediments from the EPR sites.

\section{EXPLANATORY NOTES}

\section{Organization of the Volume}

This volume is divided into an introductory chapter (Part I), site survey reports and regional geophysics (Part II), site reports (Part III), paleontologic and biostratigraphic studies (Part IV), sedimentologic 
TABLE 2

Shipboard Velocity Calibrations

\begin{tabular}{lccccc}
\hline Standard & Temperature $\left({ }^{\circ} \mathrm{C}\right)$ & $\begin{array}{c}\text { Number of } \\
\text { Measurements }\end{array}$ & True Velocity & $\begin{array}{c}\text { Average } \\
\text { Measured Velocity }\end{array}$ & $\Delta(\%)$ \\
\hline Aluminum & 1 & 6.295 & 6.290 & -0.07 \\
& 1 & & 6.279 & -0.2 \\
& 1 & & 6.166 & -2.1 \\
& 1 & & 6.352 & +1.0 \\
& 1 & & 6.321 & +0.41 \\
& 1 & & 6.271 & -0.39 \\
& 1 & & 6.295 & - \\
Distilled & 1 & & 6.298 & +0.04 \\
water & 1 & & 6.292 & -0.05 \\
& 1 & & 6.289 & -0.50 \\
Lucite & 5 & 1.498 & 1.497 & -0.05 \\
& & & & 1.490 & -0.50 \\
Brass & 1 & 2.745 & 2.731 & -0.51 \\
& 1 & & 2.743 & -0.07 \\
& 1 & 4.529 & 4.554 & +0.55 \\
& 1 & & 4.551 & +0.50 \\
& 1 & & 4.522 & -0.15 \\
\hline
\end{tabular}

studies (Part V), petrologic and geochemical studies (Part VI), rock magnetic and physical properties studies (Part VII), and syntheses (Part VIII).

Site reports for the 18 holes at 11 sites drilled are in two chapters, one each on the East Pacific Rise (Sites 419 through 423 and 426 through 429 ) and Galapagos rift (Sites 424 and 425). These two chapters are detailed summaries of the geological data obtained on Leg 54 . The presentation is brief, and has been condensed into two chapters because the sites drilled in each area are close together, and at each we recovered short, generally similar sediment and basalt sections which are best discussed on a comparative basis. By doing so, we hope to present a more comprehensive, intelligible, and concise account of Leg 54 activities. The Site Reports are organized as follows:

Site Data

Summary

Background and Objectives

Operations

Sediment Lithology

Biostratigraphy

Sediment Physical Properties

Interstitial Water Geochemistry

Igneous Petrography

Igneous Rock Chemistry

Igneous Rock Paleomagnetics

Igneous Rock Physical Properties

Conclusions

The Site Reports are co-authored by the entire scientific party with additional paleontological contributions by David Bukry and John Barron. In general, Operations were written by B. Rosendahl; sections on sediments by M. Hoffert and J. Natland (Lithology); R. Goll, D. Bukry, and J. Barron (Biostratigraphy); S. Humphris (Geochemistry); and N. Warren (Physical Properties). Sections on igneous rocks were written by R. Hekinian, E. Schrader, R. Fodor, S. Humphris, R. Srivastava, D. Mattey, Y. Dmitriev, and J. Natland (Petrography and Chemistry); N. Warren (Physical Properties); and N. Petersen and W. Roggenthen (Paleomagnetics). Background and Objectives and Conclusions were written by R. Hekinian and B. Rosendahl.

\section{Numbering of Sites, Holes, Cores, Samples}

Drill site numbers run consecutively from the first site drilled by Glomar Challenger in 1968; the site number is thus unique. A site refers to the hole or holes drilled from one acoustic positioning beacon. Several holes may be drilled at a single locality by pulling the drill string above the sea floor ("mudline") and offsetting the ship some distance (usually $100 \mathrm{~m}$ or more) from the previous hole.

The first (or only) hole drilled at a site takes the site number. Additional holes at the same site are further distinguished by a letter suffix. The first hole has only the site number; the second has the site number with the suffix $\mathrm{A}$; the third has the site number with the suffix $\mathrm{B}$; and so forth. It is important, for sampling purposes, to distinguish the holes drilled at a site, since recovered sediments or rocks usually do not come from equivalent positions in the stratigraphic column at different holes.

Cores are numbered sequentially from the top down. In the ideal case, they consist of 9.3 meters of sediment or rock in a plastic liner of $6.6 \mathrm{~cm}$ diameter. In addition, a short sample is obtained from the core catcher (a multifingered device at the bottom of the core barrel which prevents cored materials from sliding out during corebarrel recovery). This usually amounts to about 0.2 meter of sediment or rock. During Leg 54 the core catcher sample was split, described, and stored along with the rest of the core, if at all possible, taking care to maintain its proper vertical orientation. This sample represents the lowest stratum recovered in a particular cored interval.

The cored interval is the interval in meters below the sea floor measured from the point at which coring for a particular core was started to the point at which it was terminated. This interval is generally 9.5 meters (nominal length of a core barrel) but may be shorter if conditions dictate. The interval can also be longer if the core barrel was placed in the drill string during a long drilling interval. On Leg 54 almost all core intervals were 9.5 meters, because the drilling program called for nearly continuous coring.

When a core is brought aboard the Glomar Challenger, it is labeled and the plastic liner and core are cut into 1.5-meter sections. A full, 9.5-meter core would thus consist of six sections full and one 0.5 -meter section numbered from the top down, 1 to 7 . (Section 7 would consist of $0.3 \mathrm{~m}$ of the lowest sediment from the plastic liner plus the $0.2 \mathrm{~m}$ of core-catcher material.) The procedure for labeling both full and partially full cores is shown in Figure 6.

In the core laboratory on the Glomar Challenger, after routine processing, the 1.5 -meter sections of sediment core and liner are split in half lengthwise. One half is designated the "archive" half, which is described by the shipboard geologists, and photographed; and the other is the "working" half, which is sampled by the shipboard sedimentologists and paleontologists for further shipboard and shore-based analysis.

Samples taken from core sections are designated by the interval in centimeters from the top of the core sec- 

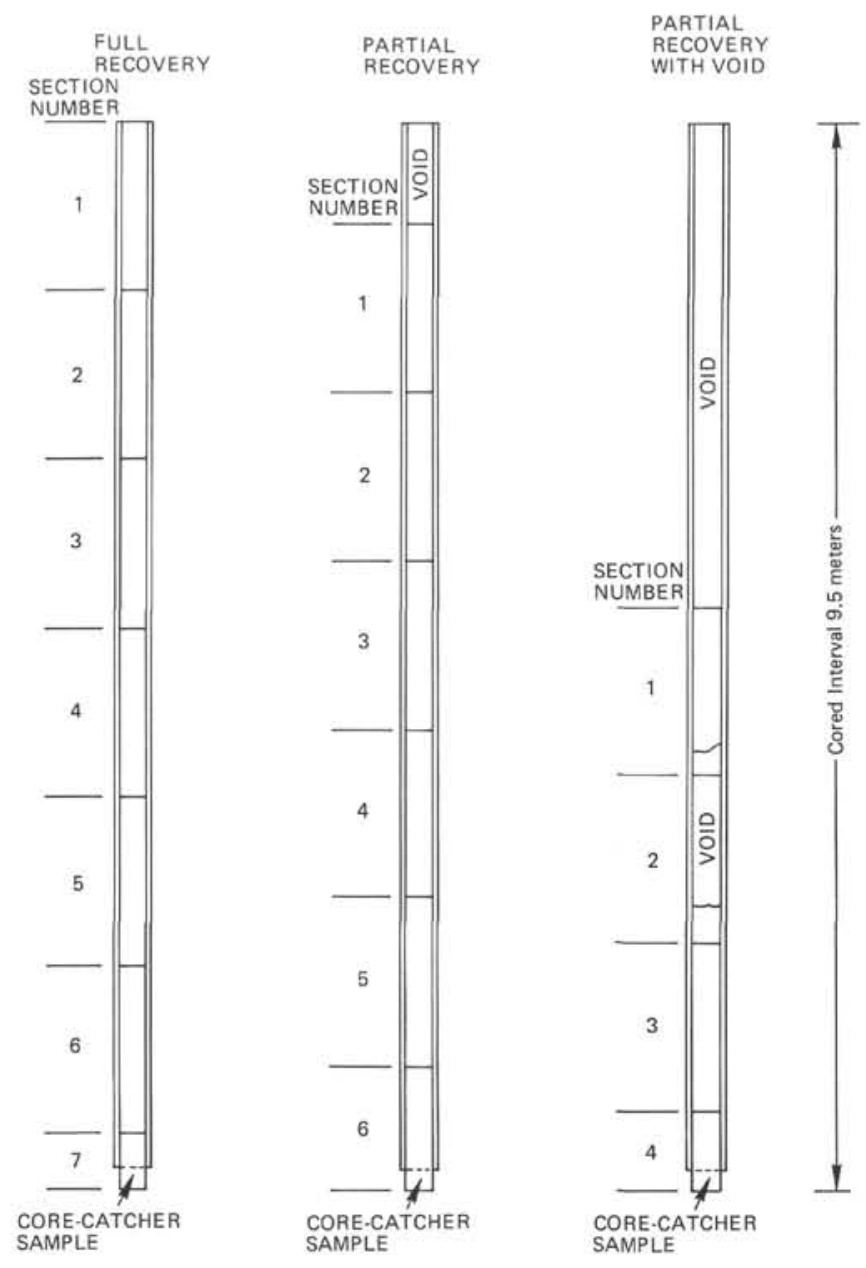

Figure 6. Diagram showing procedure for cutting and labeling core sections.

tion from which the sample was extracted; the sample size, in $\mathrm{cm}^{3}$, is also given. Thus, a full sample designation would consist of the following information:

Leg (Optional)

Site (Hole, if other than first hole)

Core Number

Section Number

Interval in centimeters from top of section

Sample 428A-4-3, 61-63 $\mathrm{cm}\left(10 \mathrm{~cm}^{3}\right)$ designates a $10-\mathrm{cm}^{3}$ sample taken from Section 3 of Core 4 from the second hole drilled at Site 428. The depth below the sea floor for this sample would then be the depth to the top of the cored interval ( $3382.5 \mathrm{~m}$ in the example above) plus 4.5 meters for Sections 1, 2, and 3, plus 0.61 meter (depth below the top of Section 3), or 3387.61 meters. Note, however, that subsequent sample requests should refer to a specific interval within a core section (in $\mathrm{cm}$ ) rather than depth in meters below the sea floor.

\section{Sediment Description Conventions}

\section{Core Disturbance}

Unconsolidated sediments are often severely disturbed by the rotary drilling/coring technique, and there is a complete gradation of disturbance style with increasing sediment induration. An assessment of degree and style of drilling deformation is made on board ship for all cored material, and shown graphically on the core description sheets. The following symbols are used:

\section{- - - - Slightly deformed; bedding contacts slight bend. \\ - - - Highly deformed; bedding completely disturbed, often showing symmetrical di- apir-like structures.}

$\bigcirc \circ \circ \circ$ Soupy, or drilling breccia; water-saturated intervals that have lost all aspects of original bedding and sediment cohesiveness.

०.०-० Biscuit structure; a drilling "breccia" in which the broken core material retains some or all aspects of original bedding.

Consolidated sediments and rocks seldom show much internal deformation, but are usually broken by drilling into cylindrical pieces of varying length. There is frequently no indication if adjacent pieces in the core liner are actually contiguous or if intervening sediment has been lost during drilling.

\section{Smear Slides}

The lithologic classification of sediments is based on visual estimates of texture and composition in smear slides made on board ship. These estimates are of areal abundances on the slide and may differ somewhat from the more accurate laboratory analyses of grain size, carbonate content, and mineralogy. Experience has shown that distinctive minor components can be accurately estimated ( \pm 1 or $2 \%$ ), but that an accuracy of \pm 10 for major constituents is more common. Carbonate content is especially difficult to estimate in smear slides, as is the amount of clay present. Smear-slide analyses at selected levels as well as averaged analyses for intervals of uniform lithology are given on the core description sheets.

\section{Carbonate Data}

Samples were taken for shore-based carbon-carbonate analysis using the LECO 70-second Analyzer. These and organic carbon values are also listed on the core description sheets.

The LECO data were used to update the carbonate content (mostly shown as nannofossil foraminifer oozes or marls) depicted in the graphic lithology column. No attempt was made to adjust smear-slide estimates or sediment names to reflect this correction.

\section{Sediment Induration}

The determination of induration is highly subjective, but field geologists have successfully made similar dis- 
tinctions for many years. The criteria of Moberly and Heath (1971) are used for calcareous deposits; subjective estimate or behavior in core cutting is used for others.

a) Calcareous sediments

Soft: Ooozes have little strength and are readily deformed under the finger or the broad plate of a spatula.

Firm: Chalks are partly indurated oozes; they are friable limestones that are readily deformed under the fingernail or the edge of a spatula blade.

Hard: Cemented rocks are termed limestones.

b) The following criteria are used for other sediments:

If the material is soft enough for the core to be split with a wire cutter, the sediment name only is used (e.g., silty clay, sand).

If the core must be cut on the band saw or diamond saw, the suffix "stone" is used (e.g., silty claystone; sandstone).

\section{Sediment Classification}

The sediment classification scheme used on Leg 54 is basically devised by the JOIDES Panel on Sedimentary Petrology and Physical Properties and adopted for use by the JOIDES Planning Committee in March 1974, with minor modifications. The classification is outlined below.

I. General rules for class limits and order of components in a sediment name.

A. Sediment assumes the names of those components present only in quantities greater than 15 percent.

B. Where more than one component is present, the component in greatest abundance is listed farthest to the right, and other components are listed progressively to the left in order of decreasing abundance.

C. The class limits are based on percentage intervals given below for various sediment types.

II. Pelagic clay

$>10 \%$ authigenic components

$<30 \%$ siliceous microfossils

$<30 \% \mathrm{CaCO}_{3}$

$<30 \%$ terrigenous components

III. Pelagic siliceous biogenic sediments

$>30 \%$ siliceous microfossils

$<30 \% \mathrm{CaCO}_{3}$

$<30 \%$ terrigenous components (mud)

Radiolarians dominant: radiolarian ooze (or radiolarite).

Diatoms dominant: diatom ooze (or diatomite).

Sponge spicules dominant: sponge spicule ooze (or spiculite).

Where uncertain: siliceous (biogenic) ooze (or chert, porcelanite).
When containing $10-30 \% \mathrm{CaCO}_{3}$ : modified by nannofossil---, foraminiferal---, calcareous---, nannofossil-foraminiferal---, or foraminiferal-nannofossil---, depending upon kind and quantity of $\mathrm{CaCO}_{3}$ component.

IV. Transitional biogenic siliceous sediments

$10-70 \%$ siliceous microfossils

$30-90 \%$ terrigenous components (mud)

$<30 \% \mathrm{CaCO}_{3}$

If diatoms < mud: diatomaceous mud (stone).

If diatoms > mud: muddy diatom ooze (muddy diatomite).

If $\mathrm{CaCO}_{3}, 10-30 \%$ : appropriate qualifier is used (see III).

V. Pelagic biogenic calcareous sediments

$$
\begin{aligned}
& >30 \% \mathrm{CaCO}_{3} \\
& <30 \% \text { terrigenous components } \\
& <30 \% \text { siliceous microfossils }
\end{aligned}
$$

Principal components are nannofossils and foraminifers; qualifiers are used as follows:

\begin{tabular}{cl}
$\begin{array}{c}\text { Foraminifer } \% \\
<10\end{array}$ & \multicolumn{1}{c}{ Name } \\
& nannofossil ooze (chalk, \\
$10-25$ & limestone) \\
& foraminiferal-nannofossil \\
$25-50$ & ooze \\
& nannofossil-foraminiferal \\
$>50$ & ooze \\
& foraminiferal ooze
\end{tabular}

Calcareous sediment containing $10-30$ per cent siliceous fossils carry the qualifier radiolarian, diatomaceous or siliceous, depending upon the identification.

VI. Transitional biogenic calcareous sediments

$>30 \% \mathrm{CaCO}_{3}$

$>30 \%$ terrigenous components

$<30 \%$ siliceous microfossils

If $\mathrm{CaCO}_{3} 30-60 \%$ : marly is used as a qualifier:

soft: marly calcareous (or nannofossil, etc.) ooze.

firm: marly chalk (or marly nannofossil chalk, etc.).

hard: marly limestone (or marly nannofossil limestone).

If $\mathrm{CaCO}_{3}>60 \%$ :

soft: calcareous (or nannofossil, etc.) ooze.

firm: chalk (or nannofossil chalk, etc.).

hard: limestone (or nannofossil limestone, etc.).

NOTE: Sediments containing $10-30 \% \mathrm{CaCO}_{3}$ fall in other classes where they are denoted with the adjective "calcareous," "nannofossil," etc.

VII. Terrigenous Sediments

$>30 \%$ terrigenous

$<30 \% \mathrm{CaCO}_{3}$

$<10 \%$ siliceous microfossils

$<10 \%$ authigenic components

Sediments in this category are subdivided into textural groups on the basis of the relative pro- 
portions of three grain-size components, i.e., sand, silt and clay. Sediments coarser than sandsize are treated as "Special Rock Types." The size limits are those defined by Wentworth (1922) (Figure 7). The textural classification is according to the triangular diagram of Shepard (1954) (Figure 8). The suffix "-stone" is used to indicate hard or consolidated equivalents of the unconsolidated sediments.

If $\mathrm{CaCO}_{3}$ is $10-30 \%$ : calcareous, nannofossil, etc. is used as a qualifier.

Other qualifiers (e.g., feldspathic, glauconitic, etc.) are used for components $>10 \%$.

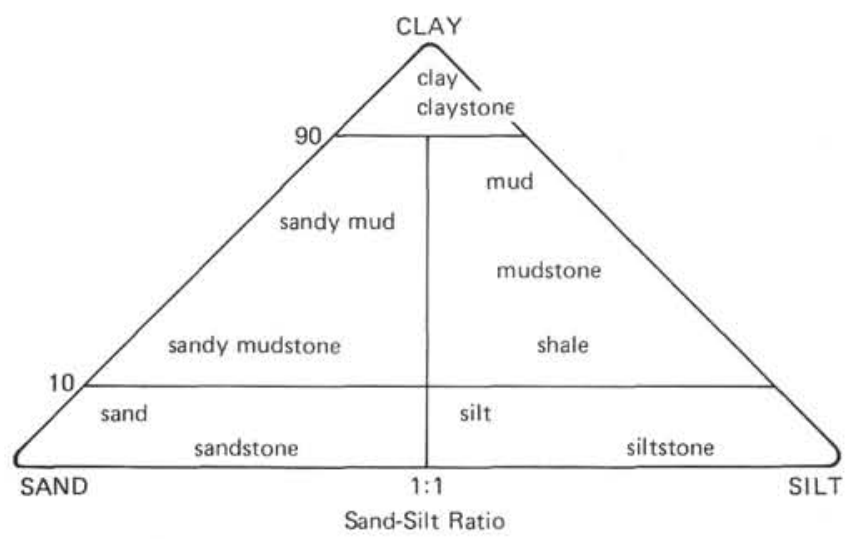

Figure 7. Terminology and class intervals of grade scales.

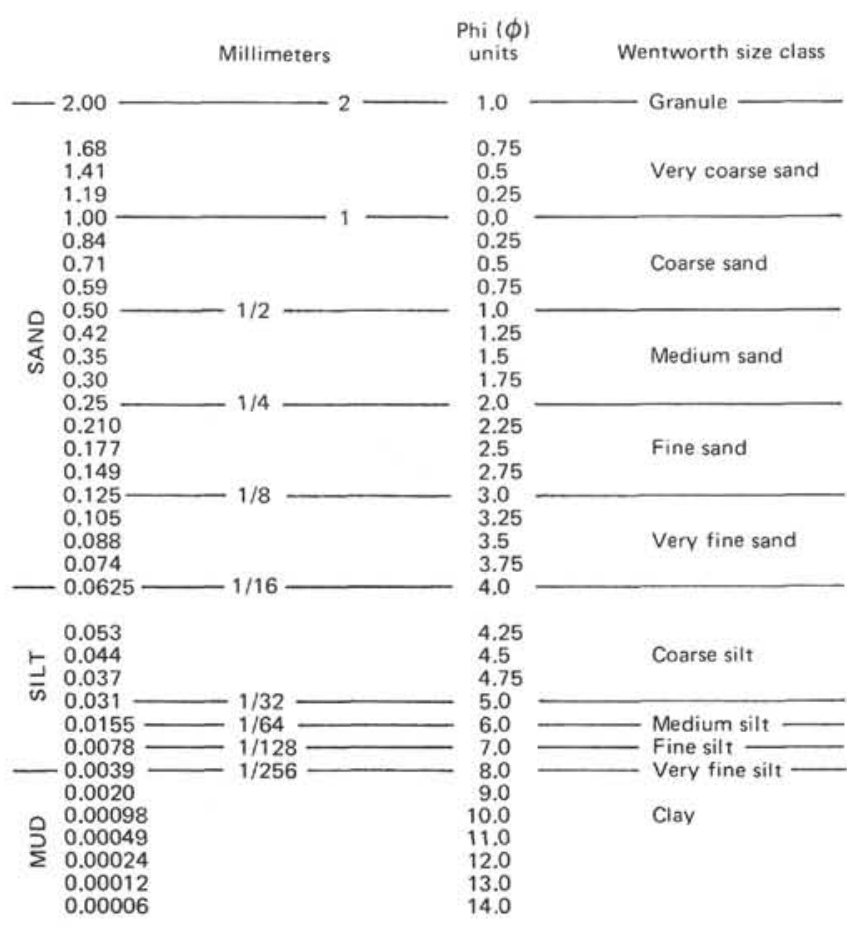

Figure 8. Textural groups - terrigenous sediments.
VIII. Volcanic sediments

a) Pyroclastic rocks are described according to the textural and compositional scheme of Wentworth and Williams (1932). The textural groups are:

Volcanic breccia $32 \mathrm{~mm}$

Volcanic lapilli $32 \mathrm{~mm}$

Volcanic ash (tuff, if indurated) 4 $\mathrm{mm}$

Compositionally, these pyroclastic rocks are described as vitric (glass), crystal, or lithic.

b) Clastic sediments of volcanic provenance are described in the same fashion as the terrigenous sediments, noting the dominant composition of the volcanic grains where possible.

At Site 424 , we encountered a variety of FeMn-rich sediments and green muds which probably are a product of near sea-floor hydrothermal activity in the oceanic crust. These we call "Fe-Mn deposits" and "green hydrothermal (?) muds," respectively.

\section{Lithologic Symbols}

Figure 9 shows the graphic symbols used to depict the lithologies encountered on Leg 54.

\section{Core Forms}

The core forms provide a variety of data and are compiled at the back of each Site Report. Shipboard paleontological determinations are provided in appropriate columns along the left hand margin. In the column headed "Graphic Lithology," appropriate symbols are used to depict lithologies found in the cores. The columns titled "Drilling Disturbance" and "Sedimentary Structures" provide information on these aspects of the cores according to the conventions previously described. Drilling disturbance symbols were shown in the section "Sediment Description Conventions" under the heading "Core Disturbance." Conventions relating to sedimentary structures are shown on Figure 10. All smear slides made aboard the ship are appropriately located in the column headed "Lithologic Samples."

The broad column headed "Lithologic Description" provides a variety of data. Along the left margin are found the color descriptions according to the Munsell color designations. All smear slides (abbreviated SS) are identified by a centimeter designation corresponding to that shown in the "Lithologic Sample" column. The percentage occurrence of each constituent is indicated, based on visual estimates. Estimates of the carbonate constituents may vary by small or large amounts from those determined by the LECO.

\section{Biostratigraphy}

Radiolarian studies on Leg 54 (R. M. Goll) use the equatorial Pacific Quaternary zonation (Nigrini, 1971). 
Pelagic

Non-biogenic

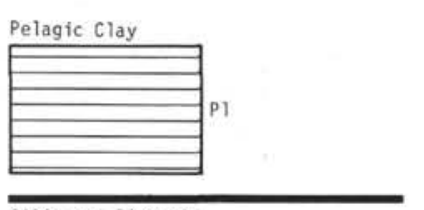

Siliceous Biogenic

Pelagic Siliceous Biogenic - Soft

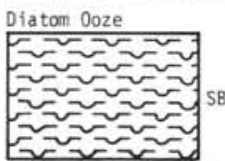

Pelagic Siliceous Biog

Radiolarian Ooze

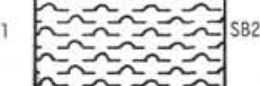

Diatomite

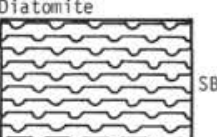

Iransitional Biogenic Siliceous Sediments

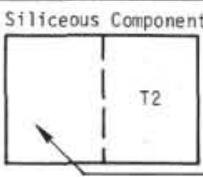

Vertical bar percent

(\%) Designation

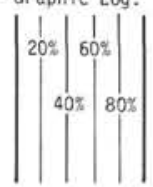

Diatom-Rad or

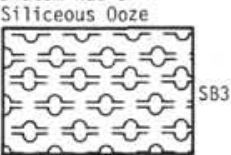

$\sim=0=0$
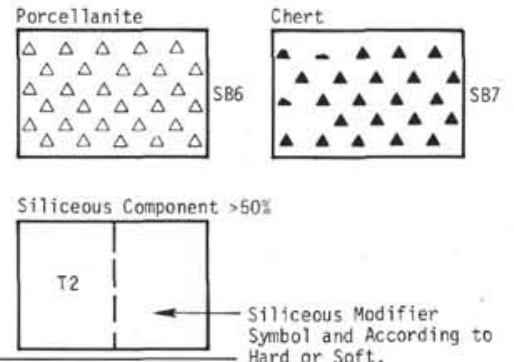

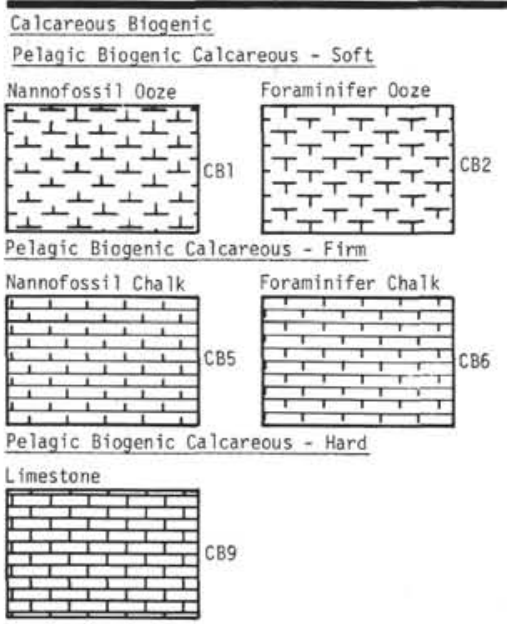

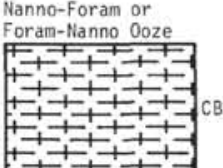

Nanno-Foram or

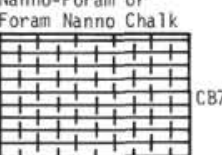

Iransitional Biogenic Calcareous Sediments

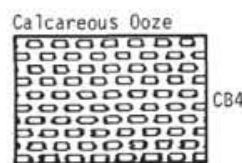

Calcareous Chalk
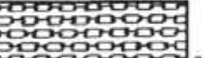

Dach

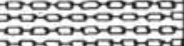

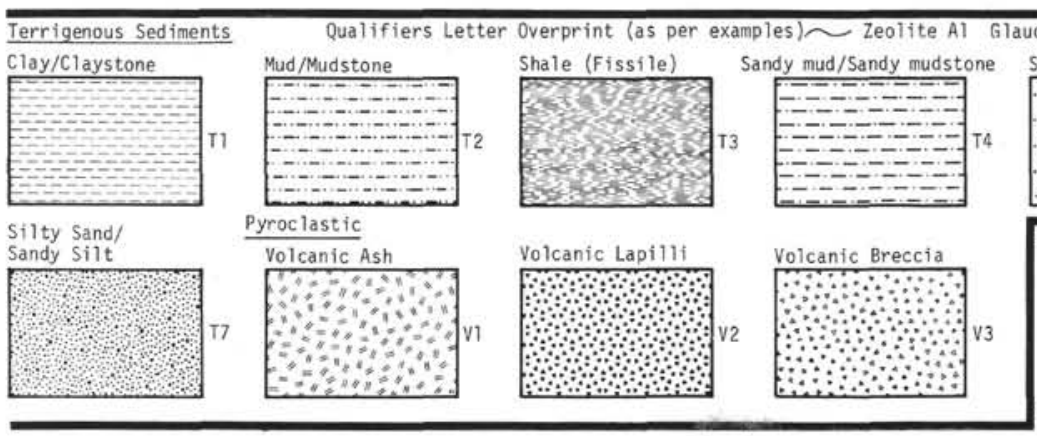

Special Rock Types
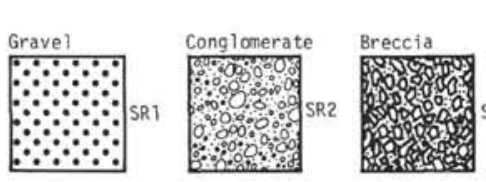

Coals
Basic Acid

Igneous Igneous

SR3 $32: 3 R 4$

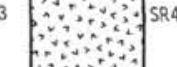
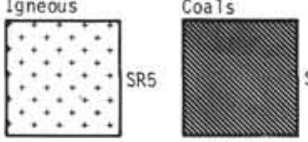

SR6

Concretions

Drawn Circle with Symbol (others may be designated)

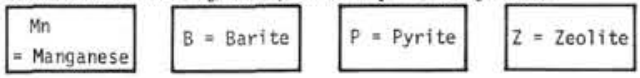

$\mathrm{Fe}-\mathrm{Mn}$ deposits and Green hydrots and inuds

Figure 9. Key to lithologic and biostratigraphic symbols. 


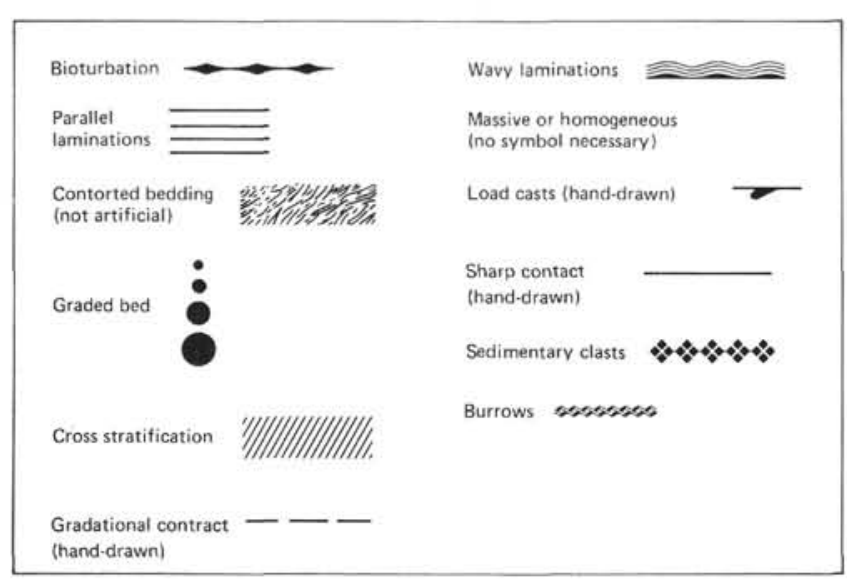

Figure 10. Sedimentary-structure symbols.

Coccolith and silicoflagellate studies (D. Bukry) employ low-latitude and eastern Pacific zonations (Bukry, 1975, 1976; Bukry and Foster, 1973). Diatom studies (J. A. Barron) use the tropical Pacific zonation (Burckle, 1972; Burckle and Updyke, 1977). Lettered diatom subzones appear in parentheses following the zone name. Preservation and abundance of diatoms and silicoflagellates are estimated from acid-cleaned, strewn-slide preparations.

\section{Basement Description Conventions}

\section{Core Forms}

Initial core description forms for igneous and metamorphic rocks are not the same as those used for sediments. The sediment barrel sheets are substantially those published in previous Initial Reports. Igneous rock representation on barrel sheets is too compressed to provide adequate information for potential sampling. Consequently, Visual Core Description forms, modified from those used onboard ship, were used for more complete graphic representation. All shipboard data per 1.5-meter section of core are listed on the modified forms as well as summary hand-specimen and thin-section descriptions. The symbols and a number of format conventions for igneous rocks used on Leg 54 are presented on Figure 11.

All basalts on Leg 54 were split using a rock saw with a diamond blade into archive and working halves. The latter was described and sampled on board ship. On a typical basalt description form (compiled at the back of each Site Report), the left column is a visual representation of the working half using the symbols of Figure 11. Two closely spaced horizontal lines in this column indicate the location of styrofoam spacers taped between basalt pieces inside the liner. Each piece is numbered sequentially from the top of each section, beginning with the number 1. Pieces are labeled on the rounded, not the sawed surface. Pieces which were possible to fit together before splitting are given the same number, but are consecutively lettered, as $1 \mathrm{~A}, 1 \mathrm{~B}, 1 \mathrm{C}$, etc. Spacers were placed between pieces with different numbers, but not between those with different letters and the same num-

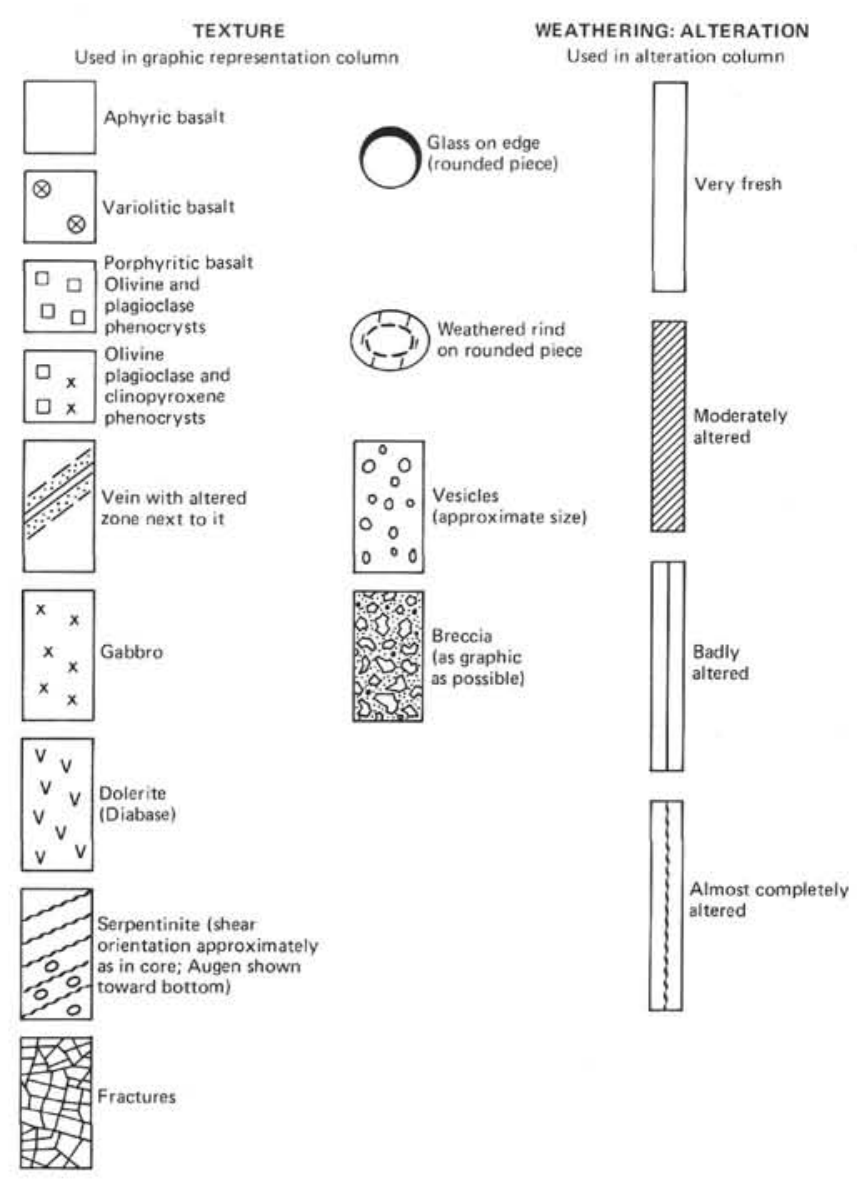

Figure 11. List of symbols for igneous rock description forms (some not applicable to Leg 54).

ber. In general, addition of spacers represents a drilling gap (no recovery). However, in cores where recovery was high, it was impractical to use spacers. In these cases, drilling gaps are indicated only by a change in numbers. All pieces have orientation arrows pointing to the top of the section, both on archive and working halves, provided the original unsplit piece was cylindrical in the liner and of greater length than the diameter of the liner. Special procedures were adopted to ensure that orientation was preserved through every step of the sawing and labeling process. All pieces suitable for sampling requiring knowledge of top from bottom are indicated by upward-pointing arrows to the left of the piece numbers on the description forms. Since the pieces were rotated during drilling, it is not possible to sample for declination studies.

Samples were taken for various measurements onboard ship. The type of measurement and approximate location are indicated in the column headed "Sample" using the following notation:

$$
\begin{aligned}
\mathrm{X} & =\mathrm{X} \text {-ray fluorescence analysis } \\
\mathrm{M} & =\text { magnetics measurements } \\
\mathrm{S} & =\text { sonic velocity measurements } \\
\mathrm{T} & =\text { thin section } \\
\mathrm{D} & =\text { density measurements } \\
\mathrm{P} & =\text { porosity measurements }
\end{aligned}
$$




\section{Igneous Rock Classification}

No igneous rocks other than basalts were recovered on Leg 54. Classification was based mainly on mineralogy of minerals visible in hand specimens, and secondarily on texture and thin-section data (usually based on 1000 point counts per thin section).

Basalts are termed aphyric, sparsely phyric, or moderately phyric depending on the proportion of phenocrysts visible with the binocular microscope $(\sim \times 12)$. Aphyric basalts were so called if phenocrysts were absent. In a practical vein, this meant that if one piece of basalt was found with a phenocryst or two in a section with all other pieces lacking phenocrysts, and no other criteria such as grain size or texture distinguished this basalt from the others, then it too was described as aphyric. A note of the rare phenocrysts, however, was included in the general description. This was done in order to restrict the number of lithologic units to those with clearly distinctive and persistent visual differences.

Sparsely phyric basalts are those with 1 to 2 per cent phenocrysts present in almost every piece of a given core or section. Clearly contiguous pieces without phenocrysts were included in this category, again with the lack of phenocrysts noted in the general description.

Moderately phyric basalts contain $2-10$ per cent phenocrysts. Aphyric basalts within a group of moderately phyric basalts are separately termed aphyric basalts.

The basalts are further classified by phenocryst type, preceding the terms phyric, sparsely phyric, etc. A plagioclase-olivine moderately phyric basalt contains 2-10 per cent phenocrysts, most of them plagioclase, but with some olivine.

\section{REFERENCES}

Bougault, H., 1977. Major elements: Analytical chemistry onboard and preliminary results. In Aumento, F., Melson, W. G., et al., Initial Reports of the Deep Sea Drilling Project, v. 37: Washington (U.S. Government Printing Office), p. 643 .

Boyce, R. E., 1976. Definitions and laboratory techniques of compressional sound velocity parameters and wet-water content, wet-bulk density, and porosity parameters by gravimetric and gamma ray attenuation techniques. In Schlanger, S. O., Jackson, E. D., et al., Initial Reports of the Deep Sea Drilling Project, v. 33: Washington (U.S. Government Printing Office), p. 931-958.
Bukry, D., 1975. Coccolith and silicoflagellate stratigraphy, northwestern Pacific Ocean, Deep Sea Drilling Project Leg 32. In Larson, R. L., Moberly, R., et al., Initial Reports of the Deep Sea Drilling Project, v. 32: Washington (U.S. Government Printing Office), p. 677-701.

, 1976. Silicoflagellate and coccolith stratigraphy, southeastern Pacific Ocean, Deep Sea Drilling Project Leg 34. In Yeats, R. S., Hart, S. R., et al., Initial Reports of the Deep Sea Drilling Project, v. 34: Washington (U.S. Government Printing Office), p. 715-735.

Bukry, D. and Foster, J. H., 1973. Silicoflagellate and diatom stratigraphy, Leg 16, Deep Sea Drilling Project. In van Andel, T. J., Heath, G. R., et al., Initial Reports of the Deep Sea Drilling Project, v. 16: Washington (U.S. Government Printing Office), p. 815-871.

Burckle, L. H., 1972. Late Cenozoic planktonic diatom zones from the Eastern Equatorial Pacific, Nova Hedwigia Beihefte, v. 39, p. 217-246.

Burckle, L. H. and Updyke, N. D., 1977. Late Neogene diatom correlations in the circum-Pacific, Internat. Congr. Pacific Neogene Strat., First, Tokyo, Proc., p. 255-284.

Lonsdale, P., 1977. Deep-tow observations at the mounds abyssal hydrothermal field, Galapagos Rift, Earth Planet. Sci. Lett., v. 36, p. 92-110.

Melson, W. G., Rabinowitz, P. D., Natland, J. H., Bougault, H., and Johnson, H. P., 1978. Cruise objectives and major results, analytical procedures and explanatory notes. In Melson, W. G., Rabinowitz, P. D., et al., Initial Reports of the Deep Sea Drilling Project, v. 45: Washington (U.S. Government Printing Office), p. 5-20.

Moberly, R., Jr. and Heath, G. R., 1971. Carbonate sedimentary rocks from the western Pacific: Leg 7, Deep Sea Drilling Project. In Winterer, E. L., Riedel, W. R., et al., Initial Reports of the Deep Sea Drilling Project, v. 7, Part 2: Washington (U. S. Government Printing Office), p. $977-$ 985.

Nigrini, C., 1971. Radiolarian zones in the Quaternary of the equatorial Pacific Ocean. In Funnell, B. M. and Riedel, W. R. (Eds.), The Micropaleontology of Oceans: Cambridge (Cambridge University Press), p. 443-461.

Sclater, J. G. and Klitgord, K. D., 1973. A detailed heat flow, topographic, and magnetic survey across the Galapagos spreading center at $86^{\circ} \mathrm{W}, J$. Geophys. Res., v. 78, p. 6951-6975.

Shepard, F. P., 1954. Nomenclature based on sand-silt-clay ratios, J. Sediment. Petrol., v. 24, p. 151-158.

Wentworth, C. K., 1922. A scale of grade and class terms of clastic sediments, J. Geol., v. 30, p. 377.

Wentworth, C. K. and Williams, H., 1932. The classification and terminology of the pyroclastic rocks, Rept. Comm. Sedimentation, Bull. Nat. Res. Counc., no. 80, p. 10-53. 


\section{APPENDIX}

Scaling Wave Technique for Measuring Velocities on Shipboard

Figure $i$ is a block diagram of the system. Instrument settings for the frequency generator and the oscilloscope are given under "Instrument Settings;" the system's modus operandi is described under "Measurement Steps."

VELOCITY MEASUREMENT/equipment schematic

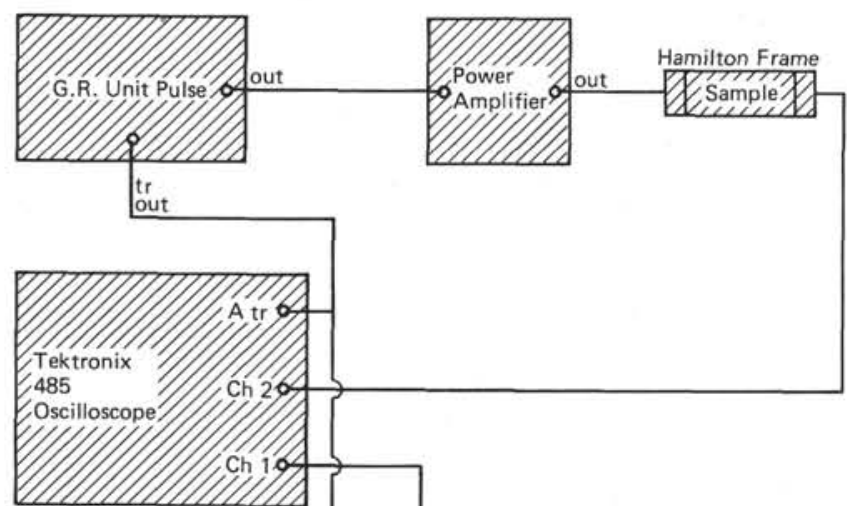

Exact

$126 \mathrm{VCF} /$

Sweep

Generator

(N)

Frequency Counter

(N)

Parts belonging to the regular velocity measuring system are hatched. Two additional instruments for the "scaling wave" and the "pick point" methods are marked by the letter $\mathrm{N}$.

\section{Instrument Settings}

Tektronix 485

A triggering: external trigger from unit pulse generator coupling: AC

source: EXT

sweep mode: normal

B triggering:

coupling: AC

source: "B runs after delay time"

A trigger hold off: "norm" position

Horizontal display: "INTEN"

Time/div. and delay time: $2 \mu \mathrm{s}$

Ch. 2: from frame

coupling AC

$1 \mathrm{M} \Omega$

(volts $/$ div, $=10 \mathrm{mV}$ )

Ch. 1: from $126 \mathrm{VCF} /$ Sweep Generator output coupling AC

$1 \mathrm{M} \Omega$

$($ volts $/$ div. $=5 \mathrm{~V})$

Vertical mode: alt.

Ch. 2 polarity: invert

BW limit: in

\section{Exact $126 \mathrm{VCF} /$ Sweep Generator}

Trig in: from B + Gate of Tektronix (rear panel)

Range (Hz): $3 \mathrm{MHz}$

Output: to scope (Tektronix 485) Ch.

Output: electrical " $T$ " to frequency counter

Function: sine

Main mode: gate

\section{Measurement Steps}

1. On 126 VCF: adjust the trigger level so the gated sine wave displays a flat initial base line $\mathrm{b}$ (Figure $i i$ ).

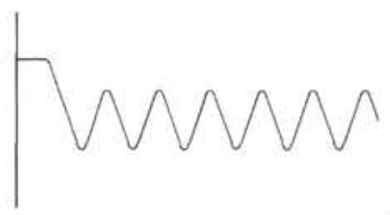

2. Adjust the amplitude to give an approximate 5-volt display on the Tektronix oscilloscope.

3. Adjust the zero starting level so that the base line is aligned with the top of sine waves (Figure iii).

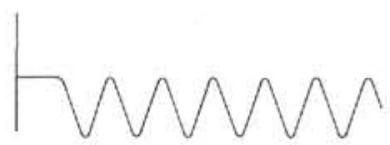

No sample adjustment

4. Transducers in contact; i.e., no sample.

5. Set the Horizontal Display on oscilloscope (485) to "INTEN."

6. Adjust the Delay time dial on oscilloscope (485) until the display appears as in Figure $i v$. This is the zero-time (no sample setting).

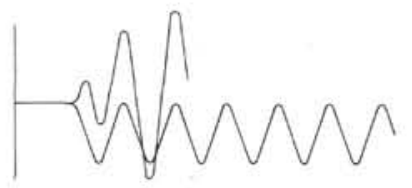

(iv)

\section{Measurement of Sample}

7. Place sample in the Hamilton Frame.

8. Adjust Multiplier on 126 VCF until signal arrival is marked by a scaling wave as shown in Figure $v$. There should be about 10 waves $(\mathrm{N}=10)$ between start of the scale and the signal's first arrival. Record N.

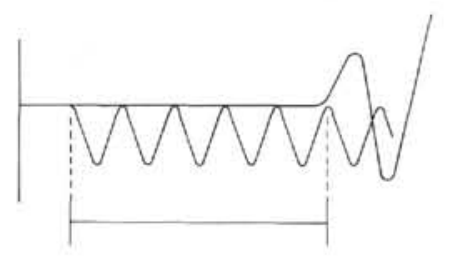

9. On the $126 \mathrm{VCF}$, turn Main Mode switch to "RUN," record the frequency $f$ from the frequency counter

travel time $(s)=\mathrm{N} / \mathrm{f} ;$ for $\mathrm{f}$ in $\mathrm{MHz}$ 